\title{
Individualized treatment of chronic hepatitis $C$ with pegylated interferon and ribavirin
}

This article was published in the following Dove Press journal:

Pharmacogenomics and Personalized Medicine

10 March 2010

Number of times this article has been viewed

\author{
Roberto J Carvalho-Filho' \\ Olav Dalgard ${ }^{2}$ \\ 'Division of Gastroenterology, \\ Hepatitis Section, Federal \\ University of São Paulo, São Paulo, \\ Brazil; ${ }^{2}$ Department of Medicine, \\ Rikshospitalet, Oslo, Norway
}

\begin{abstract}
Chronic infection with hepatitis $\mathrm{C}$ virus (HCV) is a major public health problem, with perhaps 180 million people infected worldwide. A significant proportion of these will eventually develop clinical complications, such as cirrhosis, liver decompensation and hepatocellular carcinoma. Sustained virological response (SVR) to antiviral therapy is associated with improvement in liver histology and survival free of liver-related complications. Great effort has been made to improve SVR rate by adapting the duration of therapy according to HCV genotype and to on-treatment response. Rapid virological response (RVR, undetectable HCV RNA at week 4) usually has a high positive predictive value for achieving SVR and early virological response (EVR, $\geq 2 \log$ reduction or undetectable HCV RNA at week 12) exhibits a high negative predictive value for non-response. Individualized approach can improve cost-effectiveness of HCV antiviral therapy by reducing side effects and the costs of therapy associated with unnecessary exposure to treatment and through extending therapy for those with unfavorable features. This article summarizes recent data on strategies of individualized treatment in naïve patients with mono-infection by the different HCV genotypes. The management of common side effects, the impact of HCV infection on health-related quality of life and the potential applications of host genomics in HCV therapy are also briefly discussed.
\end{abstract}

Keywords: hepatitis C, pegylated interferon, individualized treatment, genotype, genomics

\section{Introduction}

Chronic infection with hepatitis $\mathrm{C}$ virus (HCV) is a major public health problem, with perhaps 180 million people infected worldwide. ${ }^{1}$ Natural history studies indicate that around $20 \%$ to $30 \%$ of patients with chronic hepatitis $\mathrm{C}$ will eventually develop clinical complications, such as cirrhosis, liver decompensation and hepatocellular carcinoma. ${ }^{2,3}$ The estimated number of deaths associated with HCV-related complications is 8000 to 10,000 in the United States and more than 86,000 in Europe, annually., ${ }^{4,5}$ In addition, HCV infection is the leading cause of liver transplantation both in the United States and Europe. ${ }^{6,7}$ A population-based study identified that HCV-related mortality has increased significantly between 1995 and 2004, particularly among persons aged 55 to 64 years, males, African-Americans, and Native Americans. ${ }^{8}$ It has also been estimated that HCV-related deaths will likely continue to increase over the next two decades. $^{9-12}$

The ultimate goal of HCV therapy is to prevent liver-related complications and death. Since chronic hepatitis $C$ usually exhibits a very slow progression, these events occur several decades after infection. For that reason, a sustained virological response (SVR), defined as the absence of HCV RNA from serum by a sensitive PCR assay
Pavillon Abrami, Hopital Beaujonn, $100 \mathrm{Bd}$ du General Leclerc, 92110 Clichy, France Email odalgard@medisin.uio.no 
24 weeks following discontinuation of therapy has been considered a "virological cure" and a surrogate marker of benign long-term clinical outcome. ${ }^{13}$ In fact, eradication of $\mathrm{HCV}$ is associated with improvement in liver histology and survival free of liver-related complications. ${ }^{14-16}$

This article summarizes recent data on strategies of individualized treatment in naïve mono-infected patients infected by different HCV genotypes. The management of common side effects, the impact of HCV infection on health-related quality of life and the potential applications of genomics in HCV therapy are also briefly discussed.

\section{Individualized therapy - historical perspective}

The effectiveness of HCV treatment has steadily increased since the first trials of monotherapy with standard interferon alpha (IFN $\alpha)$ in 1986 to the large registration trials of pegylated IFN $\alpha$ (PEG-IFN $\alpha) \cdot{ }^{17-23}$ In the first period, $10 \%$ to $20 \%$ of patients would achieve a sustained virological response (SVR) to monotherapy with IFN $\alpha .{ }^{17,18}$ In a second period, the addition of ribavirin to IFN $\alpha$ increased the SVR rate to $40 \%{ }^{20,21}$ Finally, SVR was obtained in $55 \%$ of cases after administration of PEG-IFNo in combination with ribavirin. ${ }^{22,23}$

Comparison of nucleotide sequences of HCV variants in patients of different risk groups and geographic areas has revealed at least 6 distinct genotypes (genotypes 1, 2, 3, $4,5,6)$. These variants/genotypes differ in $30 \%$ to $35 \%$ of nucleotide sites. ${ }^{24,25}$ The greatest variability is seen within genes encoding for envelope proteins E1 and E2; core genes and genes encoding for nonstructural proteins are preserved. Within each genotype, subtypes have been identified that differ in nucleotide sites by $15 \%$ to $25 \%{ }^{26}$

The major features of HCV infection are shared by all genotypes, though steatosis develops more frequently in patients with genotype 3 than in patients with other genotypes. ${ }^{27}$ The main biologic difference among HCV genotypes is the striking variation in response to IFN $\alpha$. Only $10 \%$ to $20 \%$ of patients with genotype 1 achieve SVR with IFN $\alpha$ monotherapy, whereas the rate is $50 \%$ in patients with genotype 2 or 3 . With the pegylation of IFN $\alpha$ and the addition of ribavirin, $40 \%$ to $50 \%$ patients with genotype 1 achieve SVR compared with $80 \%$ of those with genotypes 2 or $3 .^{22,23,28} \mathrm{~A}$ basic understanding of the mechanisms behind these differences remains unknown, although a study by Neumann and colleagues suggests that IFN $\alpha$ more effectively blocks viral replication, and increase free virion clearance and death rate of cells infected with HCV genotype 2 compared to genotype $1 .{ }^{29}$
The high response rate observed in genotype 2 and 3 patients suggested that these would need shorter and less intense therapy than patients with other genotypes ${ }^{30,31}$ and this was well demonstrated in a registration trial authored by Hadziyannis et al. ${ }^{28}$ In this study, patients were treated with PEG-IFN $\alpha 2 \mathrm{a}$ and ribavirin and randomized to 4 treatment arms: A, 24 weeks of treatment with fixed dose of ribavirin (800 mg/day); B, 24 weeks of treatment with weight-based dose of ribavirin (1000 to $1200 \mathrm{mg} /$ day); C, 48 weeks of treatment with fixed dose of ribavirin; and D, 48 weeks of treatment with weight-based dose of ribavirin. Patients with genotype 1 had the highest SVR (52\%) if treated with high weight-based ribavirin dose for 48 weeks and the lowest (29\%) if treated with low fixed dose of ribavirin for 24 weeks. Stratifying patients according to baseline viral load confirmed a higher SVR rate in those with low viral load than high (Figure 1). However, a benefit of prolonged therapy with high dose of ribavirin was observed in both groups. In this study, patients with genotype 2 and 3 were grouped together. In these patients, it was found that there was no benefit from either prolonging therapy beyond 24 weeks or by increasing the dose of ribavirin to more than $800 \mathrm{mg}$ (Figure 2).

Mainly based on the Hadziyannis trial, ${ }^{28}$ most experts have recommended standard HCV treatment for genotype 1 infection as a 48-week therapy with PEG-IFN $\alpha$ ( 2 a or 2 b) associated with weight-based dose of ribavirin. For genotype $2 / 3$ patients, it is proposed a 24 -week treatment with PEG-IFN $\alpha$ (2a or 2b) combined with a fixed dose of $800 \mathrm{mg}$ of ribavirin. ${ }^{32}$ Later research has attempted to further tailor therapy on the presumption that maybe some patients could achieve non-inferior SVR rates with therapy shorter than 24 weeks and some may need treatment longer than 48 weeks. This individualized approach can improve cost-effectiveness of HCV antiviral therapy by reducing side effects and costs of therapy associated with unnecessary exposure to treatment and through extending therapy for those with slow responses. ${ }^{33}$

\section{Virological responses}

The probability of achieving SVR can be accurately estimated by assessing on-therapy response. In fact, the evaluation of viral load decay during therapy has been considered the main parameter to determine optimal duration of HCV treatment, a strategy known as "response-guided therapy". Hence, several types of virological responses have been defined based on the kinetics of serum HCV RNA decline:

1. Rapid virological response (RVR): undetectable HCV RNA at week 4 of therapy, using a test with a lower limit of detection of $50 \mathrm{IU} / \mathrm{mL}$. 


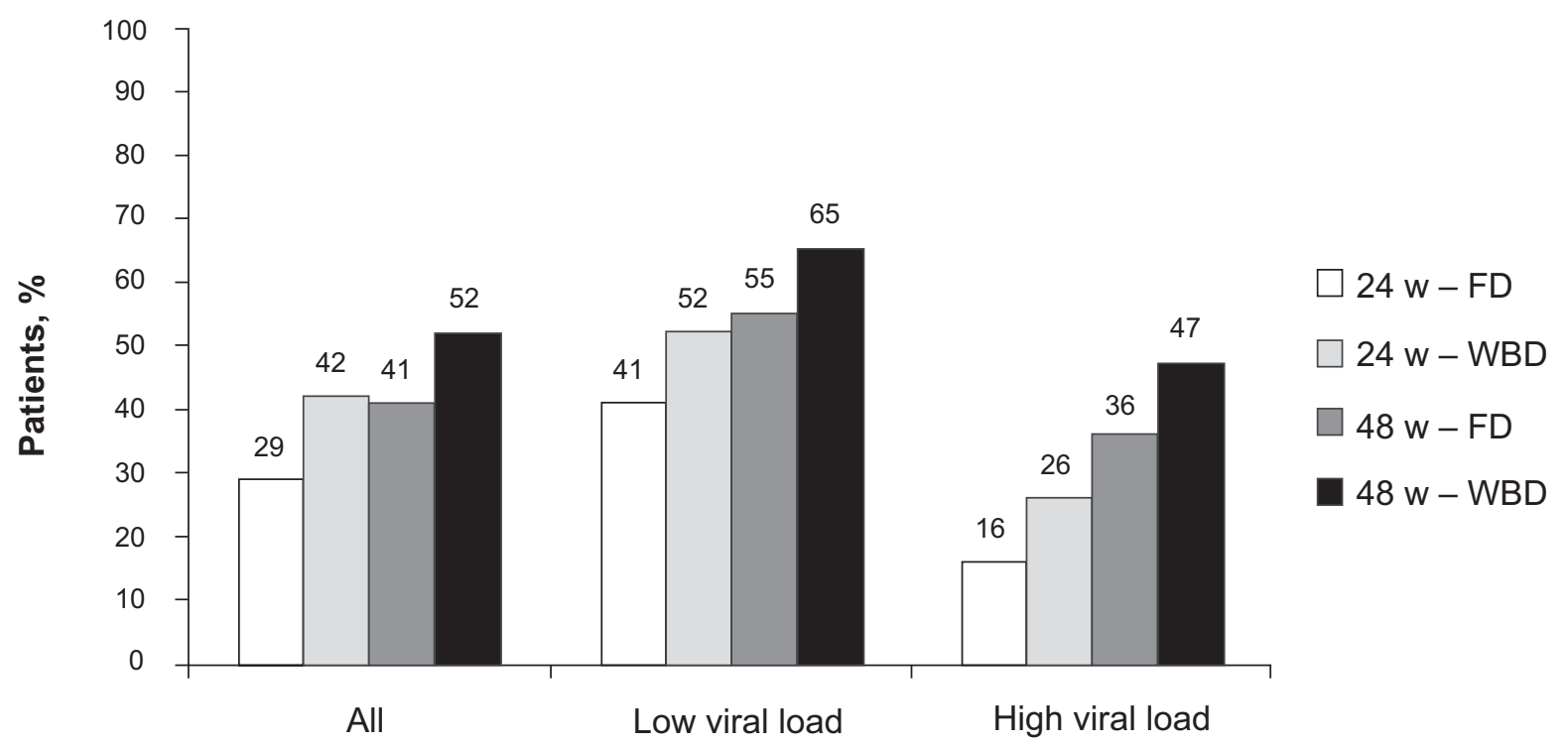

Figure I SVR in patients with genotype I and high $(>800,000 \mathrm{IU} / \mathrm{mL})$ and low $(\leq 800,000 \mathrm{IU} / \mathrm{mL})$ viral load. Patients were randomly treated for 24 and 48 weeks with pegylated interferon $\alpha 2 \mathrm{a}\left(\mathrm{I} 80 \mu \mathrm{g} /\right.$ week) and a low fixed dose (FD, $800 \mathrm{mg} /$ day) or a higher weight-based dose (WBD, 1000 to $1200 \mathrm{mg} /$ day) of ribavirin. ${ }^{28}$

2. Early virological response (EVR): defined as a $\geq 2 \log$ reduction (compared to the baseline level) or undetectable HCV RNA in serum at week 12 of treatment. EVR can be further divided into partial EVR and complete EVR, according to HCV RNA status (still detectable in partial EVR and undetectable in patients with complete EVR).

RVR is observed in approximately $12 \%$ to $47 \%$ of Western genotype 1 patients, ${ }^{34-41} 43 \%$ to $68 \%$ in Asian genotype 1 subjects, ${ }^{42,43}$ and in $61 \%$ to $78 \%$ of those with genotype 2 or 3 , irrespective of origin. ${ }^{44-50}$ Patients with RVR have a high probability of achieving SVR, with positive predictive values ranging from $71 \%$ to $96 \%$ in different studies. ${ }^{34-52}$ Likewise, EVR is more frequently seen in genotype 2 or 3 patients than in those infected with genotype 1 (94\%-97\% vs $73 \%-81 \%$, respectively). ${ }^{38,51,53}$ The absence of EVR is the most accurate predictor of failure to achieve SVR, with negative predictive value of $93 \%$ to $100 \% .^{23,38,51-54}$

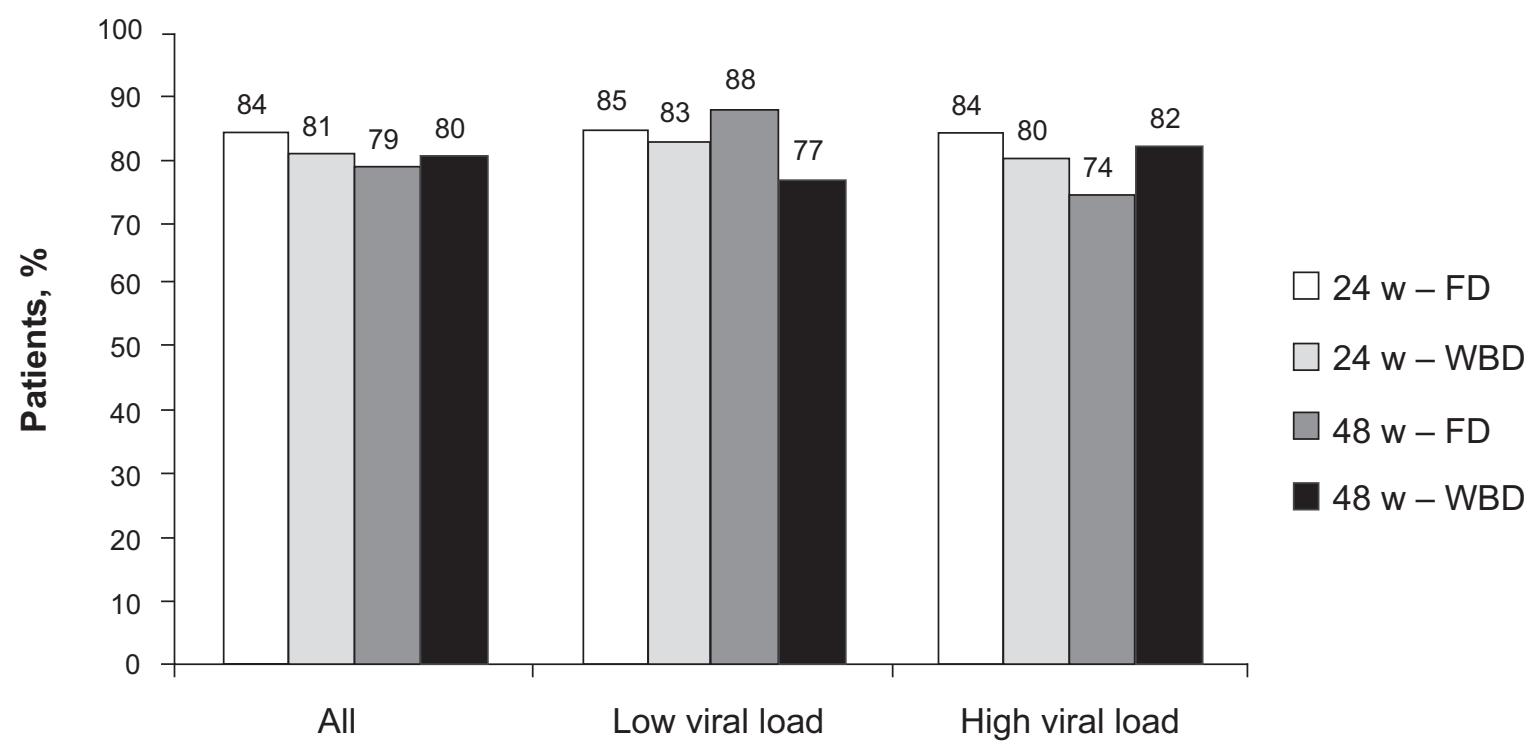

Figure 2 SVR in patients with genotype $2 / 3$ and high $(>800,000 \mathrm{IU} / \mathrm{mL})$ and low $(\leq 800,000 \mathrm{IU} / \mathrm{mL})$ viral load. Patients were randomly treated for 24 and 48 weeks with pegylated interferon $\alpha 2 \mathrm{a}\left(180 \mu \mathrm{g} /\right.$ week) and a low fixed dose (FD, $800 \mathrm{mg} /$ day) or a higher weight-based dose (WBD, 1000 to $1200 \mathrm{mg} /$ day) of ribavirin. ${ }^{28}$ 


\section{Treatment of HCV infection with genotype I \\ Standard therapy}

The combination of PEG-IFN $\alpha$ and ribavirin is the current standard regimen for the treatment of chronic hepatitis C. ${ }^{32}$ There are two licensed pegylated interferons, PEG-IFN $\alpha 2 b$ (Peg-Intron $^{\circledR}$; Schering Plough Corp) with a $12-\mathrm{kDa}$ linear polyethylene glycol (PEG) molecule, and PEG-IFNo2a (Pegasys $^{\circledR}$; Hoffmann-La Roche) with a 40-kDa branched PEG, both given subcutaneously. The newly published IDEAL study suggested that there is no significant difference in SVR rates between the two PEG-IFNs. ${ }^{59}$ In addition, this study showed that the standard dose of PEG-IFN $\alpha 2 b$ in the treatment of genotype 1 infection should be $1.0 \mu \mathrm{g} / \mathrm{kg} /$ week and not $1.5 \mu \mathrm{g} / \mathrm{kg} /$ week. Daily dose of oral ribavirin should be weight-based ( $800 \mathrm{mg}$ if weight $\leq 65 \mathrm{~kg} ; 1000 \mathrm{mg}$ if weight is between 65 and $85 \mathrm{~kg} ; 1200 \mathrm{mg}$ for patients with 85 to $105 \mathrm{~kg}$; and $1400 \mathrm{mg}$ for those with $>105 \mathrm{~kg}$ ). ${ }^{22,56}$ PEG-IFN $\alpha 2 \mathrm{a}$ is administered at a fixed dose of $180 \mu \mathrm{g} / \mathrm{week}$. With this type of PEG-IFN $\alpha$, patients with weight $\leq 75 \mathrm{~kg}$ and those with $>75 \mathrm{~kg}$ should receive $1000 \mathrm{mg}$ /day and $1200 \mathrm{mg} /$ day of ribavirin, respectively. ${ }^{23}$ Standard duration of therapy for genotype 1 patients is 48 weeks, irrespective of the PEG-IFN $\alpha$ molecule.

\section{Stopping rule}

Retrospective analysis of the two pivotal studies with pegylated interferon suggested that patients unable to achieve a decrease of serum HCV RNA $\geq 2 \log$ at week (EVR) were very unlikely to benefit from prolonged treatment. ${ }^{23,54}$ Various studies have further confirmed that only $\sim 3 \%$ of subjects without EVR eventually achieve SVR. ${ }^{38,51-53}$ Hence, it is recommended that antiviral therapy should be stopped in these patients. . $^{32,57-60}$

\section{Short treatment to rapid responders (Table I)}

Several studies have investigated the response to 24 weeks of treatment in selected genotype 1 patients (Table 1). A post hoc analysis of the study by Hadziyannis et al ${ }^{28}$ sought to identify genotype 1 patients that did not profit from increasing PEG-IFNo2a treatment from 24 to 48 weeks. ${ }^{35}$ It was observed that $20 \%(146 / 729)$ had a RVR and that these patients had a SVR rate of $88 \%$ after only 24 weeks of treatment compared to $83 \%$ after 48 weeks. The limited number of patients did not permit an adequate analysis of the effect of ribavirin dose. Even though these results are encouraging, definite conclusions cannot be drawn from this study alone.

Ferenci et al found RVR in 150/516 (29\%) in a prospective study including predominantly genotype $1(87 \%)$ treated with PEG-IFN $\alpha 2 a$ and ribavirin. ${ }^{39}$ In patients with RVR, treatment was stopped after 24 weeks. The SVR rate was $80 \%$ and the virological relapse rate was $7 \%$. No control group was included in this study.

Mangia et al randomized genotype 1 patients into 2 main groups: a control group treated with a 48-week standard therapy with PEG-IFN $\alpha 2 a$ or PEG-IFN $\alpha 2 b$

Table I Summary of the main studies evaluating individualized therapy in patients with genotype I

\begin{tabular}{|c|c|c|c|c|c|c|c|c|}
\hline \multirow[t]{2}{*}{ Short treatment } & \multirow[t]{2}{*}{$\mathbf{n}$} & \multirow{2}{*}{$\begin{array}{l}\text { Advanced } \\
\text { fibrosis }\end{array}$} & \multirow[t]{2}{*}{ RVR } & \multirow{2}{*}{$\begin{array}{l}\text { Randomization if } \\
\text { RVR }\end{array}$} & \multicolumn{2}{|c|}{ SVR in RVR subjects } & \multirow[t]{2}{*}{ PEG-IFN $\alpha$} & \multirow[t]{2}{*}{ RBV } \\
\hline & & & & & 24 weeks & 48 weeks & & \\
\hline Jensen et $\mathrm{al}^{35}$ & 729 & $23 \%$ & $20 \%$ & No & $88 \%$ & $83 \%$ & $2 a$ & $800 \mathrm{mg}$ vs WB \\
\hline Ferenci et $\mathrm{al}^{39}$ & 516 & $21 \%$ & $29 \%$ & No & $80 \%$ & NA & $2 a$ & WB \\
\hline Mangia et $\mathrm{al}^{40}$ & 696 & $32 \%$ & $27 \%$ & Yes & $77 \%$ & $87 \%$ & $2 a / 2 b$ & WB \\
\hline Yu et $\mathrm{al}^{42}$ & 200 & $22 \% 1$ & $43 \%$ & No & $89 \%$ & $100 \%$ & $2 a$ & WB \\
\hline Liu et $\mathrm{al}^{43}$ & 308 & $21 \%$ & $65 \%$ & No & $76 \%$ & $98 \%$ & $2 a$ & WB \\
\hline \multirow[t]{2}{*}{ Long treatment } & \multirow[t]{2}{*}{$\mathbf{n}$} & \multirow[t]{2}{*}{$\begin{array}{l}\text { Advanced } \\
\text { fibrosis }\end{array}$} & \multirow[t]{2}{*}{ SR } & \multirow[t]{2}{*}{ Randomization } & \multicolumn{2}{|c|}{ SVR in SR subjects } & PEG-IFN $\alpha$ & RBV \\
\hline & & & & & 72 weeks & 48 weeks & & \\
\hline Pearlman et $\mathrm{al}^{61}$ & 361 & $26 \%$ & $32 \%$ & Yes & $38 \%$ & $18 \%$ & $2 b$ & WB \\
\hline Mangia et $\mathrm{al}^{40}$ & 696 & $32 \%$ & $10 \%$ & Yes & $63 \%$ & $38 \%$ & $2 a / 2 b$ & WB \\
\hline Buti et $a^{62}$ & 1419 & NA & II\% & Yes & $48 \%$ & $43 \%$ & $2 b$ & WB \\
\hline
\end{tabular}

'All cirrhotic patients.

Abbreviations: RVR, rapid virological response (serum HCV RNA $<50 \mathrm{IU} / \mathrm{mL}$ at week 4); SVR, sustained virological response (serum HCV RNA $<50$ IU/mL 24 weeks after the end of therapy); PEG-IFN $\alpha$, pegylated interferon; RBV, daily dose of ribavirin; WB, weight-based; NA, not available; SR, slow response (viral load drop $\geq 2$ log within 12 weeks, HCV RNA positive at week 12, and HCV RNA negative at week 24). 
$(n=237)$ and an individualized duration group $(n=459)$, in which different durations were used according to the time when HCV RNA first became undetectable. ${ }^{40}$ In patients with RVR (185/696, 27\%), SVR was observed in $77 \%$ and $87 \%$ of subjects $(P=0.12)$ and the relapse rates were $19 \%$ and $10 \%$ for 24 and 48 weeks, respectively $(P=0.13)$. In the subgroup of RVR patients with baseline viremia $<400.000 \mathrm{IU} / \mathrm{mL}$, SVR rate was $83 \%$ in the 48 -week group and $84 \%$ in those treated by 24 weeks $(P=0.83)$.

Two studies from Taiwan with genotype 1 subjects confirmed that a 24-week therapy is associated with higher relapse and lower SVR rates. ${ }^{42,43}$ Both studies also suggested that RVR patients with low baseline viremia present comparable SVR rates when treated for 24 or 48 weeks.

Altogether, based on the available data, one cannot as yet recommend 24 weeks therapy to all genotype 1 patients with RVR. However, based on case-by-case analysis, a 24-week treatment could be considered in genotype 1 subjects with RVR that experience significant side effects, particularly in those with low viremia at baseline. It remains to be defined which cutoff is the most accurate value to define low viremia, $400,000,600,000$ or $800,000 \mathrm{IU} / \mathrm{mL}$.

\section{Long treatment to slow responders (Table I)}

Only $50 \%$ of genotype 1 patients achieve SVR. A subgroup of patients seems to respond slowly to treatment. The question has been raised whether these slow responders would have a better chance of achieving SVR if treatment was prolonged beyond 48 weeks to 72 weeks (Table 1). Pearlman et al defined slow response as having a viral load drop of $2 \log$ or more within 12 weeks, being HCV RNA positive at week 12, and being HCV RNA negative at week $24 .{ }^{61}$ In this single center US trial with PEG-IFN $\alpha 2 \mathrm{~b}$ and weight-based ribavirin, a slow response was observed in $112 / 361$ patients (32\%) and 101 subjects were randomized to 48 or 72 weeks of therapy. SVR rates were $18 \%$ and $38 \%$ after 48 and 72 weeks of treatment, respectively $(P=0.03)$ and the relapse rates were $59 \%$ and $20 \%$, respectively $(P=0.004)$. Although these results favored extended treatment, it should be noted that this trial included a high number of African Americans (48\%), with a well described poor response to interferon. Thus, these results should be interpreted with caution.

In the study by Mangia et al, both PEG-IFN $\alpha 2 \mathrm{a}$ and $2 \mathrm{~b}$ were used together with weight-based ribavirin. Slow response was defined as being HCV RNA positive at week 8 but negative week $12 .{ }^{40}$ Using this definition, slow response was observed in 73/696 patients (10\%). Patients with slow response were treated for $48(n=21)$ or $72(n=52)$ weeks. A SVR was achieved in 38\% after 48 weeks and $63 \%$ after 72 weeks $(P=0.068)$. A virological relapse was seen in $43 \%$ and $15 \%$ after 48 and 72 weeks treatment, respectively $(P=0.057)$.

Recently, data from the SUCCESS trial, a large, multicenter, European study with genotype 1 slow responders treated with PEG-IFN $\alpha 2 b$ and weight-based ribavirin has been published in abstract form. ${ }^{62}$ In this randomized controlled trial, like in Pearlman's study, ${ }^{61}$ patients with detectable HCV RNA and a viral load decline $\geq 2 \log$ at week 12 but with undetectable HCV RNA at week 24 were considered as slow responders. Undetectable HCV RNA at week 12 was observed in 816 subjects (57\%), who were treated with a standard duration therapy of 48 weeks. At week 24, 159/1419 (11\%) slow responders were randomized to 48 - or 72-week therapy. No difference was seen in SVR rates between groups ( $43 \%$ vs $48 \%$, after 48 and 72 weeks, respectively; $P=\mathrm{NS})$.

Two other trials have assessed the impact of prolonged treatment on SVR in slow responders. ${ }^{34,36}$ Both trials used PEG-IFN $\alpha 2 \mathrm{a}$ and $800 \mathrm{mg} /$ day of ribavirin as a fixed dose and found a benefit with a 72 -week treatment vs 48 weeks. However, the use of a non-standard dose of ribavirin makes the interpretation of these studies difficult.

In the study by Berg et al, ${ }^{34}$ dropout rates were significantly higher in the extended treatment arm, as compared to the standard duration one ( $41 \%$ vs $24 \%$, respectively). Likewise, in the SUCCESS trial, ${ }^{62}$ dropouts were also more frequent in the 72-week arm, but in this trial even among those treated per protocol, no significant gain was achieved by prolonging treatment beyond 48 weeks.

The discrepant results between the above-mentioned trials have at least two possible explanations: the use of fixed vs weight-based ribavirin and the use of different PEG-IFNs. As the IDEAL trial failed to show significant difference between PEG-IFNs regarding SVR rates, ${ }^{55}$ we believe that the dosing of ribavirin has had the strongest impact on treatment outcome in these trials. Hence, optimizing ribavirin dose may be more important than prolonging treatment. When optimal dosing proves impossible to maintain, prolonged therapy may be considered.

In summary, although a 72-week prolonged treatment may result in improved SVR rates in a subset of slow responders, available data are insufficient to clearly identify which patients would benefit from extended antiviral therapy. Hence, a recommendation to slow responders regarding 
prolonged treatment beyond 48 weeks cannot be made at present.

\section{Treatment of HCV infection with genotypes $\mathbf{2}$ and $\mathbf{3}$}

\section{Standard therapy}

Combination therapy with PEG-IFN $\alpha 2 \mathrm{a}$ or $2 \mathrm{~b}$ plus ribavirin represents also the standard of care for patients infected with genotypes 2 or 3. ${ }^{28,63}$ Recommended doses for PEG-IFN $\alpha 2 b$ is $1.5 \mathrm{m \mu g} / \mathrm{kg} /$ week and $180 \mathrm{~m} \mu \mathrm{g} /$ week for PEG-IFN $\alpha 2 \mathrm{a}$. Patients with genotypes 2 and 3 can be treated with low dose ribavirin ( $800 \mathrm{mg}$ ) and for only 24 weeks, without a negative impact on SVR rates. ${ }^{28}$

\section{Stopping rule}

The 12-week stopping rule is not clinically useful in genotype $2 / 3$ subjects, since more than $95 \%$ of these patients clear $\mathrm{HCV}$ by the week 12. A modified stopping rule based on failure to achieve RVR does not seem to be helpful either, given its low negative predictive value for SVR in those infected by genotype 2 and 3, when treated for 24 weeks $(\sim 40 \%))^{38,49}$

\section{Short treatment to rapid responders (Table 2)}

The study by Hadziyannis et al showed a high and equal response to 24 and 48 weeks combination treatment with PEG-IFN $\alpha 2 \mathrm{a}$ in patients with genotype 2 or 3, regardless of ribavirin dosage (SVR rates ranging from $79 \%$ to $84 \%$ ). ${ }^{28}$ The next question is whether these individuals (or a subgroup of them) would do as well with even shorter treatment. This was assessed in an uncontrolled pilot trial by Dalgard et al. ${ }^{44}$ In this study, RVR was obtained by 95/122 (78\%) subjects with genotype 2 or 3 . Patients with RVR received only 14 weeks of treatment while the remaining received the standard 24-week treatment. PEG-IFN $\alpha 2 \mathrm{~b}$ was used and ribavirin was dosed high and according to weight (800 to $1400 \mathrm{mg}$ /day). In the group who received 14-week treatment, 90\% achieved SVR and among those without RVR the SVR rate was $56 \%$. These good results were confirmed by Mangia et al, who randomized 283 patients 3:1 to either standard 24-week therapy $(1.0 \mu \mathrm{g} / \mathrm{kg} /$ week of PEG-IFN $\alpha 2 \mathrm{~b}$ plus ribavirin) or to a variable schedule with 12 weeks to those with RVR and 24 weeks to the remaining. ${ }^{45}$ Among subjects with RVR, SVR was achieved in $85 \%$ and $91 \%$ after 12 and 24 weeks of therapy, respectively (difference of $-6 \% ; 95 \% \mathrm{CI},-16$ to +4$)$.

In a third trial, Dalgard et al randomized patients with RVR to 14 and 24 weeks of combination treatment with $1.5 \mu \mathrm{g} / \mathrm{kg} /$ week of PEG-IFN $\alpha 2 \mathrm{~b}$ plus ribavirin. ${ }^{50}$ In this study, RVR was achieved in 299/432 (71\%). In a modified intention to treat analysis, the SVR rates were $86 \%$ and $93 \%$ after 14 and 24 weeks, respectively (difference of $-6.9 \%$; 95\% $\mathrm{CI},-0.1$ to +13.9 ). Considering only those patients who were treated per protocol, SVR rates were $90 \%$ in the 14 -week group and $94 \%$ in the 24-week group. Overall, it was found that patients with genotype 2 responded better than those with genotype 3 and that those with low viral load responded better than those with high viremia $(>400.000 \mathrm{IU} / \mathrm{mL})$. However, prolongation of treatment was not shown to be more beneficial to "difficult-to-treat" patients (genotype 3 with high viremia), as compared to those "easy-to-treat" subjects (genotype 2 with low viremia) (Table 3 ).

A post hoc analysis of a large genotype $2 / 3$ registration trial largely confirmed the above findings. ${ }^{47}$ In this trial, called ACCELERATE, 1465 patients were randomized to 16- or 24-week treatment with PEG-IFN 2 a and fixed dose of $800 \mathrm{mg}$ of ribavirin, among whom $65 \%$ had RVR. In patients with RVR treated for 16 weeks, the SVR rate was $79 \%$ and in those treated for 24 weeks it was $85 \%(P=0.02)$.

Table 2 Summary of the main studies evaluating individualized therapy in patients with genotype 2 and 3

\begin{tabular}{|c|c|c|c|c|c|c|c|c|c|}
\hline \multirow{2}{*}{$\begin{array}{l}\text { Short } \\
\text { treatment }\end{array}$} & \multirow[t]{2}{*}{$\mathbf{n}$} & \multirow[t]{2}{*}{ G2-G3 } & \multirow{2}{*}{$\begin{array}{l}\text { Advanced } \\
\text { fibrosis }\end{array}$} & \multirow[t]{2}{*}{ RVR } & \multirow{2}{*}{$\begin{array}{l}\text { Randomization } \\
\text { if } R V R\end{array}$} & \multicolumn{2}{|c|}{ SVR in RVR subjects } & \multirow[t]{2}{*}{ PEG-IFN $\alpha$} & \multirow[t]{2}{*}{ RBV } \\
\hline & & & & & & SVR/Duration & 24 weeks & & \\
\hline Dalgard et a ${ }^{44}$ & 122 & $24 \%-76 \%$ & $23 \%$ & $78 \%$ & No & $90 \% / 14$ weeks & - & $2 b$ & WB \\
\hline Mangia et $\mathrm{al}^{45}$ & 283 & $75 \%-25 \%$ & $18 \%$ & $63 \%$ & Yes & $85 \% / 12$ weeks & $91 \%$ & $2 b$ & WB \\
\hline Dalgard et $\mathrm{a}^{50}$ & 428 & $20 \%-80 \%$ & NA & $71 \%$ & Yes & $86 \% / 14$ weeks & $93 \%$ & $2 b$ & WB \\
\hline Shiffman et al ${ }^{47}$ & 1465 & $50 \%-50 \%$ & $24 \%$ & $65 \%$ & No & $79 \% / 16$ weeks & $85 \%$ & $2 a$ & $800 \mathrm{mg}$ \\
\hline Lagging et a $\mathrm{a}^{49}$ & 382 & $27 \%-73 \%$ & $49 \%$ & $62 \%$ & No & $71 \% / 12$ weeks & $91 \%$ & $2 a$ & WB \\
\hline Yu et $\mathrm{al}^{48}$ & 150 & $100 \%-0 \%$ & $21 \%$ & $87 \%$ & No & $100 \% / 12$ weeks & $98 \%$ & $2 a$ & WB \\
\hline
\end{tabular}

Abbreviations: G2-G3, proportion of patients with genotype 2 and 3; RVR, rapid virological response (serum HCV RNA $<50$ IU/mL at week 4); SVR, sustained virological response (serum HCV RNA $<50 \mathrm{IU} / \mathrm{mL} 24$ weeks after the end of therapy); PEG-IFN $\alpha$, pegylated interferon; RBV, daily dose of ribavirin; WB, weight-based; NA, not available. 
Table 3 Impact of HCV baseline viral load and genotype on sustained virological response therapy in patients with genotype 2 and 3

\begin{tabular}{|c|c|c|c|c|c|}
\hline & \multirow{3}{*}{$\begin{array}{l}\text { Dalgard I et al }{ }^{44} \\
\text { SVR, n (\%) } \\
\text { I4 Weeks }\end{array}$} & \multirow{2}{*}{\multicolumn{2}{|c|}{$\begin{array}{l}\text { Mangia et } \text { al }^{45} \\
\text { SVR, } n(\%)\end{array}$}} & \multirow{2}{*}{\multicolumn{2}{|c|}{$\begin{array}{l}\text { Dalgard } 2 \text { et } \mathrm{al}^{50} \\
\text { SVR, n (\%) }\end{array}$}} \\
\hline & & & & & \\
\hline & & I 2 Weeks & 24 Weeks & I4Weeks & 24 Weeks \\
\hline All & $85 / 95(90)$ & II3/I33 (85) & $4 I / 45$ (9I) & $120 / 139(86)$ & $136 / 146(93)$ \\
\hline Genotype 3 & 66/74 (89) & $24 / 31$ (77) & $10 / 10(100)$ & $93 / 110(84)$ & $106 / 115(92)$ \\
\hline Low viral load ${ }^{a}$ & $39 / 40$ (98) & $7 / / 2(58)$ & - & $29 / 36(80)$ & $44 / 44(100)$ \\
\hline High viral load & $26 / 33(79)$ & $17 / 19$ (89) & - & $57 / 66(86)$ & $57 / 66(86)$ \\
\hline Genotype 2 & |9/2| (91) & $89 / 102(87)$ & $31 / 35$ (89) & $27 / 29(93)$ & $30 / 31$ (97) \\
\hline Low viral load ${ }^{a}$ & $12 / 13(92)$ & $43 / 46(93)$ & - & $6 / 6(100)$ & $I I / I I(100)$ \\
\hline High viral load & $7 / 8$ (88) & $46 / 56(82)$ & - & $20 / 22(90)$ & $18 / 19(95)$ \\
\hline
\end{tabular}

Notes: SVR, sustained virological response (serum HCV RNA $<50 \mathrm{IU} / \mathrm{mL} 24$ weeks after the end of therapy). a Low viral load: $<00,000 \mathrm{U} / \mathrm{mL}$ in Dalgard I et al and in Mangia et al; and <400,000 IU/mL in Dalgard 2. 'High viral load: $>600,000 \mathrm{IU} / \mathrm{mL}$ in Dalgard I et al and in Mangia et al and >400,000 IU/mL in Dalgard 2 .

In view of these trials, it seems that the antiviral response to short treatment is very good, but not as good as after a 24-week course. The difference in response seems to be around $5 \%$ in favor of longer treatment. Therefore, the number needed to treat for 24 weeks, instead of 12 to 14 weeks, to achieve one SVR would be of approximately 20 . What the most cost-effective approach would be remains to be determined.

Approximately $10 \%$ to $15 \%$ relapse after short treatment. Mangia et al studied the effect of retreating these patients for 24 weeks and found that 30/43 (70\%) of such patients achieved SVR after a second therapy. ${ }^{40}$ Dalgard et al found that treating all RVR patients with short therapy and retreating the relapsers would be more cost-effective than treating all for 24 weeks. ${ }^{50}$

Thus, European and Asian studies suggest that patients with genotype 2 or 3 infection and RVR may be treated for 12 weeks and retreated in case of relapse. However, it should be emphasized to the patient that this approach carries a $10 \%$ to $15 \%$ risk of a second therapy of 24 weeks being necessary. Patients without RVR should be treated for 24 weeks. If short therapy is chosen, ribavirin should be dosed according to weight. There are several subpopulations in which short therapy approach has not yet been well evaluated, like HIV-HCV co-infected patients, cirrhotic individuals, liver transplanted subjects and those of African origin. Until new data become available, these patients should receive standard therapy.

\section{Long treatment to slow responders}

Up to now, there are no published trials addressing the efficacy of longer treatment in genotype 2 or 3 patients exhibiting slow virological response. However, a retrospective pooled analysis of Fried's and Hadziyannis' trials suggested that a combination of higher doses of ribavirin (1000 to $1200 \mathrm{mg} /$ day) and a longer duration of therapy (48 weeks) improved SVR in genotype 2 and 3 subjects without RVR. ${ }^{64}$
This population will be included in the ongoing NCORE $2 / 3$ trial, a randomized, open-label study comparing 24 vs 48 weeks of combination therapy with PEG-IFN $\alpha$ 2a plus weight-based ribavirin. ${ }^{65}$

\section{Treatment of HCV infection with other genotypes Genotype 4}

The efficacy of combination therapy with PEG-IFN $\alpha$ plus ribavirin in genotype 4 subjects was confirmed in four prospective studies, three of them with a randomized controlled design. ${ }^{39,66-68}$ Originally, based on preliminary studies with SVR rates similar to those achieved in genotype 1 infection, the recommended duration of therapy for these patients was 48 weeks. In fact, Kamal et al observed a lower SVR rate after 24-week combination treatment with PEG-IFN $\alpha 2 \mathrm{~b}$ plus ribavirin as compared to 36 - and 48 -week regimens ( $29 \%$ vs $66 \%$ and $69 \%$, respectively; $P=0.001$ ) ${ }^{66}$ Although global SVR rates were not different between 36- and 48-week groups ( $66 \%$ vs $69 \%, P=0.3$ ), $65 \%$ of subjects with high viral load at baseline ( $>2$ million copies $/ \mathrm{mL}$ ) achieved higher SVR rate when treated for 48 weeks, as compared to $35 \%$ in the 24 -week group $(P=0.04)$. In this study, irrespective of treatment duration, no patient without EVR achieved SVR, suggesting that genotype 4 patients without EVR would not benefit from continuing therapy. In a second trial with 378 patients, the feasibility of response-guided treatment in this population has been confirmed. ${ }^{68}$ In this trial, 60/378 (16\%) of subjects were randomized to a control group treated with standard dose of PEG-IFN $\alpha 2 \mathrm{~b}$ plus $10.6 \mathrm{mg} / \mathrm{kg} /$ day of ribavirin for 48 weeks. The remaining patients $(n=318,84 \%)$ were treated according to on-therapy response: those with RVR were treated for 24 weeks ( $\mathrm{n}=69,22 \%$ ), subjects with complete EVR (undetectable HCV RNA at week 12) were 
treated for 36 weeks $(n=79,25 \%)$, and those with partial EVR ( $\geq 2 \log$ drop and detectable HCV RNA after 12 weeks) received therapy for 48 weeks $(n=160,50 \%)$. The overall SVR rate of the variable-duration groups was comparable to 48 -week fixed duration group (68\% vs 58\%), with better compliance and fewer side effects as compared to controls. Within each variable-duration group, SVR rates were $86 \%$, $76 \%$ and $56 \%$ in patients with RVR, complete EVR and partial EVR, respectively. Nevertheless, as opposed to the previous trial, EVR showed a low negative predictive value to predict failure to achieve SVR, in both variable-duration and control groups (40\% and 54\%, respectively). Finally, Ferenci et al observed SVR in 26/30 genotype 4 patients with RVR (87\%) after 24 weeks of treatment with PEG-IFN $\alpha$ 2a and ribavirin. ${ }^{39}$

To sum up, genotype 4 patients should receive combination therapy of PEG-IFN $\alpha$ (standard dosage) and high, weight-based dose of ribavirin (1000 to $1200 \mathrm{mg} /$ day) for 48 weeks. We still lack sufficient data to recommend individualized therapy to this group. In the future we hope to see further investigations elucidating this promising approach.

\section{Genotype 5}

Most cases of HCV genotype 5 infections occur in South Africa, where it has been reported as the most prevalent genotype. ${ }^{69,70}$ Since there are insufficient data on optimal schedule, these subjects should receive the same standard regimen as proposed for those with genotype 1 .

\section{Genotype 6}

In some countries of Southeast Asia (Vietnam, Thailand), the reported prevalence of $\mathrm{HCV}$ infection is as high as $6 \%$, and genotype 6 accounts for approximately $30 \%$ of the cases. ${ }^{71}$ Two studies have assessed virological response to PEG-IFN $\alpha$ combined with ribavirin in HCV genotype 6 infection. ${ }^{72,73}$ These studies have shown SVR rates of $75 \%$ and $86 \%$ but they included only 56 patients in total. Compared to a standard 48-week schedule, therapy for 24 weeks was associated with lower SVR rate $39 \%$ vs $75 \%, P=0.044) .{ }^{72}$ Hence, it is currently recommended that subjects with HCV genotype 6 infection should be treated like genotype 1 and 5 patients.

\section{Side effects of antiviral therapy}

Treatment with PEG-IFN $\alpha$ and ribavirin is hampered by frequent and sometimes serious side effects. Among the latter are autoimmune diseases, significant hemolytic anemia and severe depression. Except from hemolytic anemia, side effects are believed to be mostly IFN-related. It should however be mentioned that ribavirin can carry an increased risk of birth defects. Therefore, proper contraception during and within 6 months after therapy must be used. Other minor side effects like cough and skin rash also seem to be mainly associated with ribavirin.

A few hours after the first injection with PEG-IFN $\alpha$, the majority of patients will experience a flu-like syndrome with myalgia, headache, fatigue and fever. Generally, these symptoms are managed by common analgesics and by improving oral hydration. After 4 to 6 weeks, the flu-like syndrome gradually resolves.

Depression may be induced by IFN $\alpha$, with an incidence of $20 \%$ to $30 \%{ }^{74}$ Most commonly, it develops after three months of treatment. Mild and moderate depression can be handled with conservative measures by nonpsychiatrist professionals. However, the development of moderate depression may require reduction of PEG-IFN $\alpha$ dosage with or without prescription of an antidepressant (usually, a selective inhibitor of serotonin uptake). If severe depression is diagnosed, $\mathrm{HCV}$ treatment should be stopped and the patients should be immediately referred to a psychiatrist.

Several autoimmune diseases have been reported to occur during HCV treatment, including systemic lupus erythematosus, psoriasis, type I diabetes mellitus, Graves' disease and hypothyroidism..$^{75-77}$

IFN $\alpha$ exerts a myelosuppressive effect, sometimes leading to significant thrombocytopenia and leucopenia. ${ }^{22,23}$ This toxic effect of IFN $\alpha$ increases the problem of ribavirininduced hemolytic anemia, which develops to some degree in most patients. Thrombocytopenia during IFN $\alpha$ treatment is rarely associated with clinical significant complications and it seems safe to continue with full dose as long as platelet count is superior to $30 \times 10^{9} / \mathrm{mL}$ and no bleeding episodes has been recorded. In selected cirrhotic subjects with low platelets at baseline, eltrombopag therapy may help to raise counts in order to allow the initiation of HCV therapy. ${ }^{78}$ However, this is an expensive therapy and it its effect on the SVR rate is unknown.

As with thrombocytopenia, IFN $\alpha$-related leucopenia is usually benign and it is safe to maintain the dose of PEGIFN $\alpha$ if neutrophils count is above $0.5 \times 10^{9} / \mathrm{mL}$ without signs of infections.

If hemoglobin falls to less than $10 \mathrm{~g} / \mathrm{dL}$ or a very rapid decline in hemoglobin level is seen, it is advisable to reduce the dose of ribavirin. Nonetheless, in selected subpopulations (HIV co-infection, liver transplanted patients and end-stage renal disease subjects), the use of erythropoietin may be 
justified. However, the positive impact of this approach on SVR rate remains to be documented. Interestingly, a post-hoc analysis of the IDEAL study confirmed previous findings suggesting that those who experience anemia have a greater chance of achieving SVR than those who do not..$^{55}$ This suggests that anemia may be a biological marker of adequate ribavirin exposure.

\section{Impact of HCV infection on quality of life}

Health-related quality of life (HRQOL) is reduced among HCV patients. ${ }^{79}$ Whether this is due to the chronic viral infection, due to the psychological effect of carrying a potentially deadly virus or it is a reflection of the special population (ie, drug users) that most commonly carries the virus is debatable. ${ }^{80}$ Successful virus eradication improves HRQOL either through a beneficial psychological or a biological effect. ${ }^{79}$

\section{Genomics in chronic hepatitis C}

A poorer response to $\mathrm{HCV}$ therapy has been noted in those of African and Latino origin as compared to Caucasians. ${ }^{55,81,82}$ It has also been suggested that East Asians have higher SVR rates than patients of European ancestry. ${ }^{43,83}$ Recent data derived from the IDEAL trial found a strong association between a polymorphism near the IL28B gene (encoding interferon- $\lambda-3$ ) and SVR, both among patients of European ancestry and African-Americans. ${ }^{84}$ This finding clearly suggests that host genomics plays a major role in antiviral response and provides a new approach for individualization of therapy in HCV chronic infection.

There are more than 32,000 protein-encoding genes, but the exact number of functional transcripts that are expressed in the liver is unknown. ${ }^{85,86}$ High-throughput genomics methods like microarray (MA) technology and large-scale real-time reverse transcription polymerase chain reaction (RT-PCR) has been used to identify genes associated with liver fibrogenesis and host immune response, shedding light into the intrinsic mechanisms involved in major issues of $\mathrm{HCV}$ chronic infection, like viral persistence after acute infection, ${ }^{87,88}$ liver fibrosis progression, ${ }^{89-92}$ and response to antiviral therapy. ${ }^{93-103}$ While MA analysis allows a broader search of gene expression signatures among several hundreds to thousands of mRNA transcripts in a single experiment, RT-PCR represents a targeted approach, in which it is possible to quantify the expression of relevant genes, previously selected through a hypothesis-driven research. ${ }^{104,105}$ Several groups have reported both gene expression profiles ${ }^{93-97}$ as well as single nucleotide polymorphisms (SNPs) $)^{98-103}$ that may affect response to antiviral therapy in chronic hepatitis C. Although there is some variation among the implicated genes, the vast majority of these are IFN-stimulated genes (ISGs), involved in regulatory IFN pathways. A common finding of these gene expression studies has been a higher baseline expression of ISGs in liver tissue of nonresponders, compared to patients with SVR, suggesting that ISGs are already maximally induced in non-responders before IFN $\alpha$ therapy. Whether (and how) this pretreatment higher expression of ISGs actually prevents an adequate response to exogenous PEG-IFN $\alpha$ remains to be defined. Based on the exciting findings of the above-mentioned studies, it is conceivable that, within the next few years, genomic tools will become available in clinical practice, allowing the individualization of treatment by identifying before treatment those patients with higher probability to respond to antiviral therapy.

\section{Future therapies}

New therapies like HCV NS3/4A protease inhibitors and HCV NS5B polymerase inhibitors are being developed and are eagerly anticipated. Initial results have been particularly promising with the protease inhibitors telaprevir and boceprevir, with SVR rates ranging from $61 \%$ to $75 \%$ in naïve genotype 1 patients. ${ }^{106-108}$ It is out of the scope of this review to deal with these drugs in depth, but it should be mentioned that it is likely that their use in clinical practice will be individualized as well. For instance, host genomics and/or on treatment viral response may be used to identify those who will only need double therapy with PEG-IFN $\alpha$ and ribavirin in contrast to those who will require triple therapy with $\mathrm{PEG}-\mathrm{IFN} \alpha$, ribavirin and a new antiviral drug.

\section{Future research agenda}

Several issues on the use of viral kinetics for the optimization of HCV therapy need further clarification, including:

- Health-economics of individualized therapy;

- Individualized treatment in genotype 4, 5 and 6 patients;

- Differences between genotype 2 and 3 patients;

- Influence of key baseline factors, like initial HCV viral load, advanced fibrosis, insulin resistance;

- Optimal dosing of ribavirin;

- HCV kinetics in special populations, including HIV and HBV co-infected subjects, end-stage renal disease patients, and ethnic minorities; 
- Incorporation of innovative molecular biology tools, such as transcription mediated amplification test (TMA), high-throughput genomic methods, and characterization of the liver and serum proteomes; and

- Individualized treatment in triple therapy with new drugs like protease and polymerase inhibitors.

\section{Conclusion}

Despite major advances in therapy, only about $50 \%$ of patients clear HCV infection with the current available treatment. Hence, the development of new drugs and novel treatment strategies are deemed necessary to improve outcome in chronic hepatitis C. A growing body of evidence suggests that baseline host and viral characteristics, as well as viral kinetics during treatment should be used to individualize HCV therapy. This adapted approach can improve treatment cost-effectiveness by avoiding unnecessary exposure to drugs and by identifying those requiring extended therapy. The use of viral genomics in the management of HCV infection has since long been well established. The last five years have witnessed a significant development in the field of viral kinetics as well and it is expected that the growing knowledge in host genomics will further enhance the efficacy of HCV antiviral therapy.

\section{Disclosures}

The authors declare no conflicts of interest.

\section{References}

1. Hepatitis C fact sheet. Geneva: World Health Organization. URL: http://www.who.int/mediacentre/factsheets/fs164/en/. Accessed July 13, 2009.

2. Benvegnù L, Gios M, Boccato S, Alberti A. Natural history of compensated viral cirrhosis: a prospective study on the incidence and hierarchy of major complications. Gut. 2004;53(5):744-749.

3. Niederau C, Lange S, Heintges T, et al. Prognosis of chronic hepatitis C: results of a large, prospective cohort study. Hepatology. 1998;28(6):1687-1695.

4. Cdc.gov [homepage on the Internet]. Centers for Disease Control and Prevention (US). Division of Viral Hepatitis. US disease burden data: 1980-2003. URL: http://www.cdc.gov.myaccess.library.utoronto. $\mathrm{ca} / \mathrm{ncidod} /$ diseases/hepatitis/resource/PDFs/disease_burden2004.pdf. Accessed July 18, 2008.

5. Mühlberger N, Schwarzer R, Lettmeier B, Sroczynski G, Zeuzem S, Siebert U. HCV-related burden of disease in Europe: a systematic assessment of incidence, prevalence, morbidity, and mortality. $B M C$ Public Health. 2009;22(9)34.

6. Mukherjee S, Sorrell MF. Controversies in Liver Transplantation for Hepatitis C. Gastroenterology. 2008;134(6):1777-1788.

7. Prieto M, Berenguer M, Rimola A, et al. Liver transplantation in hepatitis C. A Spanish multicentre experience. Eur J Gastroenterol Hepatol. 1998;10(9):771-776.

8. Wise M, Bialek S, Finelli L, Bell BP, Sorvillo F. Changing trends in hepatitis C-related mortality in the United States, 1995-2004. Hepatology. 2008;47(4):1128-1135.
9. Davis GL, Albright JE, Cook SF, Rosenberg DM. Projecting future complications of chronic hepatitis $\mathrm{C}$ in the United States. Liver Transpl. 2003;9(4):331-338.

10. Deuffic-Burban S, Wong JB, Valleron AJ, Costagliola D, Delfraissy JF, Poynard T. Comparing the public health burden of chronic hepatitis C and HIV infection in France. J Hepatol. 2004;40(2):319-326.

11. Sypsa V, Touloumi G, Papatheodoridis GV, et al. Future trends of HCV-related cirrhosis and hepatocellular carcinoma under the currently available treatments. J Viral Hepat. 2005;12(5):543-550.

12. Deuffic-Burban S, Poynard T, Sulkowski MS, Wong JB. Estimating the future health burden of chronic hepatitis $\mathrm{C}$ and human immunodeficiency virus infections in the United States. J Viral Hepat. 2007;14(2):107-115.

13. Maylin S, Martinot-Peignoux M, Moucari R, et al. Eradication of hepatitis $\mathrm{C}$ virus in patients successfully treated for chronic hepatitis $\mathrm{C}$. Gastroenterology. 2008;135(3):821-829.

14. Bruno S, Stroffolini T, Colombo M, et al; for Italian Association of the Study of the Liver Disease (AISF). Sustained virological response to interferon-alpha is associated with improved outcome in HCV-related cirrhosis: a retrospective study. Hepatology. 2007;45(3):579-587.

15. Veldt BJ, Heathcote EJ, Wedemeyer H, et al. Sustained virologic response and clinical outcomes in patients with chronic hepatitis $\mathrm{C}$ and advanced fibrosis. Ann Intern Med. 2007;147(10):677-684.

16. Mallet V, Gilgenkrantz H, Serpaggi J, et al. Brief communication: the relationship of regression of cirrhosis to outcome in chronic hepatitis C. Ann Intern Med. 2008;149(6):399-403.

17. Hoofnagle JH, Mullen KD, Jones DB, et al. Treatment of chronic non-A, non-B hepatitis with recombinant human alpha interferon. A preliminary report. N Engl J Med. 1986;315:1575-1578.

18. Lin R, Roach E, Zimmerman M, Strasser S, Farrell GC. Interferon alfa-2b for chronic hepatitis $\mathrm{C}$ : effects of dose increment and duration of treatment on response rates: results of the first multicentre Australian trial. J Hepatol. 1995;23:487-496.

19. Poynard T, Bedossa P, Chevallier M, et al. A comparison of three interferon alfa-2b regimens for the long-term treatment of chronic non-A, non-B hepatitis. N Engl J Med. 1995;332:1457-1462.

20. McHutchison JG, Gordon SC, Schiff ER, et al. Interferon alfa-2b alone or in combination with ribavirin as initial treatment for chronic hepatitis C. Hepatitis Interventional Therapy Group. $N$ Engl J Med. 1998;339(21):1485-1492.

21. Poynard T, Marcellin P, Lee SS, et al. Randomized trial of interferon alpha2b plus ribavirin for 48 weeks or for 24 weeks versus interferon alpha2b plus placebo for 48 weeks for treatment of chronic infection with hepatitis $\mathrm{C}$ virus. International Hepatitis Interventional Therapy Group (IHIT). Lancet. 1998;352(9138):1426-1432.

22. Manns MP, McHutchison JG, Gordon SC, et al. Peginterferon alfa-2b plus ribavirin compared with interferon alfa-2b plus ribavirin for initial treatment of chronic hepatitis C: a randomized trial. Lancet. 2001;358(9286):958-965.

23. Fried MW, Shiffman ML, Reddy KR, et al. Peginterferon alfa-2a plus ribavirin for chronic hepatitis $\mathrm{C}$ virus infection. $N$ Engl J Med. 2002;347(13):975-982.

24. Simmonds P, Holmes EC, Cha TA, et al. Classification of hepatitis C virus into six major genotypes and a series of subtypes by phylogenetic analysis of the NS-5 region. J Gen Virol. 1993;74 (Pt 11):2391-2399.

25. Simmonds P. Genetic diversity and evolution of hepatitis C virus - 15 years on. J Gen Virol. 2004;85(Pt 11):3173-3188.

26. Zein NN. Clinical significance of hepatitis C virus genotypes. Clin Microbiol Rev. 2000;13(2):223-235.

27. Rubbia-Brandt L, Quadri R, Abid K, et al. Hepatocyte steatosis is a cytopathic effect of hepatitis C virus genotype 3. J Hepatol. 2000;33(1):106-115.

28. Hadziyannis SJ, Sette H Jr, Morgan TR, et al; for PEGASYS International Study Group. Peginterferon-alpha2a and ribavirin combination therapy in chronic hepatitis C: a randomized study of treatment duration and ribavirin dose. Ann Intern Med. 2004; 140(5):346-355. 
29. Neumann AU, Lam NP, Dahari H, et al. Differences in viral dynamics between genotypes 1 and 2 of hepatitis $\mathrm{C}$ virus. J Infect Dis. 2000;182(1):28-35.

30. Tsubota A, Chayama K, Ikeda K, et al. Factors predictive of response to interferon-alpha therapy in hepatitis $\mathrm{C}$ virus infection. Hepatology. 1994;19(5):1088-1094.

31. Diodati G, Bonetti P, Tagger A, et al. Relationship between serum HCV markers and response to interferon therapy in chronic hepatitis C. Evaluation of HCV genotypes during and after long-term follow-up. Dig Dis Sci. 1994;39(11):2497-2502.

32. Ghany MG, Strader DB, Thomas DL, Seeff LB. Diagnosis, management, and treatment of hepatitis C: An update. Hepatology. 2009;49(4):1335-1374.

33. Siebert U, Sroczynski G, Aidelsburger P, et al. Clinical effectiveness and cost effectiveness of tailoring chronic hepatitis $\mathrm{C}$ treatment with peginterferon alpha-2b plus ribavirin to $\mathrm{HCV}$ genotype and early viral response: a decision analysis based on German guidelines. Pharmacoeconomics. 2009;27(4):341-354.

34. Berg T, von Wagner M, Nasser S, et al. Extended treatment duration for hepatitis $C$ virus type 1: comparing 48 versus 72 weeks of peginterferonalfa-2a plus ribavirin. Gastroenterology. 2006;130(4):1086-1097.

35. Jensen DM, Morgan TR, Marcellin P, et al. Early identification of HCV genotype 1 patients responding to 24 weeks peginterferon alpha-2a (40 kd)/ribavirin therapy. Hepatology. 2006;43(5):954-960.

36. Sánchez-Tapias JM, Diago M, Escartín P, et al; for TeraViC-4 Study Group. Peginterferon-alfa2a plus ribavirin for 48 versus 72 weeks in patients with detectable hepatitis $\mathrm{C}$ virus RNA at week 4 of treatment. Gastroenterology. 2006;131(2):451-460.

37. Zeuzem S, Buti M, Ferenci P, et al. Efficacy of 24 weeks treatment with peginterferon alfa-2b plus ribavirin in patients with chronic hepatitis $\mathrm{C}$ infected with genotype 1 and low pretreatment viremia. J Hepatol. 2006;44(1):97-103.

38. Yu JW, Wang GQ, Sun LJ, Li XG, Li SC. Predictive value of rapid virological response and early virological response on sustained virological response in $\mathrm{HCV}$ patients treated with pegylated interferon alpha-2a and ribavirin. J Gastroenterol Hepatol. 2007;22(6):832-836.

39. Ferenci P, Laferl H, Scherzer TM, et al; for Austrian Hepatitis Study Group. Peginterferon alfa-2a and ribavirin for 24 weeks in hepatitis C type 1 and 4 patients with rapid virological response. Gastroenterology. 2008;135(2):451-458

40. Mangia A, Minerva N, Bacca D, et al. Individualized treatment duration for hepatitis $\mathrm{C}$ genotype 1 patients: A randomized controlled trial. Hepatology. 2008;47(1):43-50.

41. de Segadas-Soares JA, Villela-Nogueira CA, Perez RM, Nabuco LC, Brandão-Mello CE, Coelho HS. Is the rapid virologic response a positive predictive factor of sustained virologic response in all pretreatment status genotype 1 hepatitis c patients treated with peginterferon-alpha $2 b$ and ribavirin? J Clin Gastroenterol. 2009;43(4):362-366.

42. Yu ML, Dai CY, Huang JF, et al. Rapid virological response and treatment duration for chronic hepatitis $\mathrm{C}$ genotype 1 patients: a randomized trial. Hepatology. 2008;47(6):1884-1893.

43. Liu CH, Liu CJ, Lin CL, et al. Pegylated interferon-a-2a plus ribavirin for treatment-naive asian patients with hepatitis $\mathrm{C}$ virus genotype 1 infection: a multicenter, randomized controlled trial. Clin Infect Dis. 2008;47(10):1260-1269.

44. Dalgard O, Bjøro K, Hellum KB, et al. Treatment with pegylated interferon and ribavarin in HCV infection with genotype 2 or 3 for 14 weeks: a pilot study. Hepatology. 2004;40(6):1260-1265.

45. Mangia A, Santoro R, Minerva N, et al. Peginterferon alfa-2b and ribavirin for 12 vs 24 weeks in HCV genotype 2 or 3. $N$ Engl J Med. 2005;352(25):2609-2617.

46. von Wagner M, Huber M, Berg T, et al. Peginterferon-alpha-2a (40 KD) and ribavirin for 16 or 24 weeks in patients with genotype 2 or 3 chronic hepatitis C. Gastroenterology. 2005;129(2):522-527.

47. Shiffman ML, Suter F, Bacon BR, et al; for ACCELERATE Investigators. Peginterferon alfa-2a and ribavirin for 16 or 24 weeks in HCV genotype 2 or 3. N Engl J Med. 2007;357(2):124-134.
48. Yu ML, Dai CY, Huang JF, et al. A randomized study of peginterferon and ribavirin for 16 versus 24 weeks in patients with genotype 2 chronic hepatitis C. Gut. 2007;56(4):553-559.

49. Lagging M, Langeland N, Pedersen C, et al; for NORDynamIC Study Group. Randomized comparison of 12 or 24 weeks of peginterferon alpha-2a and ribavirin in chronic hepatitis $\mathrm{C}$ virus genotype $2 / 3$ infection. Hepatology. 2008;47(6):1837-1845.

50. Dalgard O, Bjøro K, Ring-Larsen H, et al; for North-C Group. Pegylated interferon alfa and ribavirin for 14 versus 24 weeks in patients with hepatitis $\mathrm{C}$ virus genotype 2 or 3 and rapid virological response. Hepatology. 2008;47(1):35-43.

51. Ferenci P, Fried MW, Shiffman ML, et al. Predicting sustained virological responses in chronic hepatitis $\mathrm{C}$ patients treated with peginterferon alfa-2a (40 KD)/ribavirin. J Hepatol. 2005;43(3):425-433.

52. Martinot-Peignoux M, Maylin S, Moucari R, et al. Virological response at 4 weeks to predict outcome of hepatitis $\mathrm{C}$ treatment with pegylated interferon and ribavirin. Antivir Ther. 2009;14(4):501-511.

53. Diago M, Olveira A, Solá R, et al. Treatment of chronic hepatitis C genotype 1 with peginterferon-alpha2a $(40 \mathrm{kDa})$ plus ribavirin under routine clinical practice in Spain: early prediction of sustained virological response rate. Aliment Pharmacol Ther. 2007;25(8):899-906.

54. Davis GL, Wong JB, McHutchison JG, Manns MP, Harvey J, Albrecht J. Early virologic response to treatment with peginterferon alfa-2b plus ribavirin in patients with chronic hepatitis C. Hepatology. 2003;38(3):645-652.

55. McHutchison JG, Lawitz EJ, Shiffman ML, et al; IDEAL Study Team. Peginterferon alfa-2b or alfa-2a with ribavirin for treatment of hepatitis C infection. N Engl J Med. 2009;361(6):580-693.

56. Jacobson IM, Brown RS Jr, Freilich B, et al. Peginterferon alfa-2b and weight-based or flat-dose ribavirin in chronic hepatitis $\mathrm{C}$ patients: a randomized trial. Hepatology. 2007;46(4):971-981.

57. Dhumeaux D, Marcellin P, Lerebours E. Treatment of hepatitis C. The 2002 French consensus. Gut. 2003;52(12):1784-1787.

58. McCaughan GW, Omata M, Amarapurkar D, et al; for Asian Pacific Association for the Study of the Liver (APASL) Hepatitis C Working Party. Asian Pacific Association for the Study of the Liver consensus statements on the diagnosis, management and treatment of hepatitis C virus infection. J Gastroenterol Hepatol. 2007;22(5):615-633.

59. Orlent H, Vrolijk JM, Veldt BJ, Schalm SW. Hepatitis C 2002 guidelines: summary and annotations. Scand J Gastroenterol. 2003;(Suppl 239):105-110.

60. Sherman M, Bain V, Villeneuve JP, et al. The management of chronic viral hepatitis: A Canadian consensus conference 2004. Can J Infect Dis Med Microbiol. 2004;15(6):313-326.

61. Pearlman BL, Ehleben C, Saifee S. Treatment extension to 72 weeks of peginterferon and ribavirin in hepatitis c genotype 1-infected slow responders. Hepatology. 2007;46(6):1688-1694.

62. Buti M, Lurie Y, Zakharova NG, et al. Extended treatment duration in chronic hepatitis $\mathrm{C}$ genotype 1-infected slow responders: final results of the SUCCESS study [abstract]. J Hepatol. 2009;50(1 Suppl):S58.

63. Zeuzem S, Hultcrantz R, Bourliere M, et al. Peginterferon alfa-2b plus ribavirin for treatment of chronic hepatitis $\mathrm{C}$ in previously untreated patients infected with $\mathrm{HCV}$ genotypes 2 or 3. J Hepatol. 2004;40(6):993-999.

64. Willems B, Hadzyiannis SJ, Morgan TR, et al. Should treatment with peginterferon plus ribavirin be intensified in patients with $\mathrm{HCV}$ genotype $2 / 3$ without a rapid virological response? [abstract]. J Hepatol. 2007;(2 Suppl):S6.

65. Hoffmann-La Roche; Hoffmann-La Roche (Clinical Trials, Study Director). A study of combination therapy With PEGASYS (peginterferon alfa-2a (40 kD) and Copegus (ribavirin) in patients with chronic hepatitis $\mathrm{C}$ genotype 2 or 3 who do not achieve a rapid viral response. In: ClinicalTrials.gov [Internet]. Bethesda (MD): National Library of Medicine (US). 2000- [cited 2009 Jul 28]. URL: http://clinicaltrials. gov/show/NCT00623428 NLM Identifier: NCT00623428. 
66. Kamal SM, El Tawil AA, Nakano T, et al. Peginterferon alpha-2b and ribavirin therapy in chronic hepatitis $C$ genotype 4 : impact of treatment duration and viral kinetics on sustained virological response. Gut. 2005;54(6):858-866.

67. Zayadi AR, Attia M, Barakat EMF, et al. Response of hepatitis C genotype-4 naive patients to 24 weeks of peginterferon-a2b/ribavirin or induction-dose interferon-a2b/ribavirin/amantadine: a non-randomized controlled study. Am J Gastroenterol. 2005;100(11):2447-2452.

68. Kamal SM, El Kamary SS, Shardell MD, et al. Pegylated interferon alpha-2b plus ribavirin in patients with genotype 4 chronic hepatitis C: The role of rapid and early virologic response. Hepatology. 2007;46(6):1732-1740.

69. Smuts HE, Kannemeyer J. Genotyping of hepatitis C virus in South Africa. J Clin Microbiol. 1995;33:1679-1681.

70. Prabdial-Sing N, Puren AJ, Mahlangu J, Barrow P, Bowyer SM. Hepatitis $\mathrm{C}$ virus genotypes in two different patient cohorts in Johannesburg, South Africa. Arch Virol. 2008;153(11):2049-2058.

71. Nguyen MH, Keeffe EB. Chronic hepatitis C: Genotypes 4 to 9. Clin Liver Dis. 2005;9(3):411-426, vi.

72. Nguyen MH, Trinh HN, Garcia R, Nguyen G, Lam KD, Keeffe EB. Higher rate of sustained virologic response in chronic hepatitis $\mathrm{C}$ genotype 6 treated with 48 weeks versus 24 weeks of peginterferon plus ribavirin. Am J Gastroenterol. 2008;103(5):1131-1135.

73. Fung J, Lai CL, Hung I, et al. Chronic hepatitis C virus genotype 6 infection: response to pegylated interferon and ribavirin. $J$ Infect Dis. 2008;198(6):808-812.

74. Dieperink E, Willenbring M, Ho SB. Neuropsychiatric symptoms associated with hepatitis $\mathrm{C}$ and interferon alpha: A review. Am J Psychiatry. 2000;157(6):867-876.

75. Schreuder TC, Gelderblom HC, Weegink CJ, et al. High incidence of type 1 diabetes mellitus during or shortly after treatment with pegylated interferon alpha for chronic hepatitis $\mathrm{C}$ virus infection. Liver Int. 2008;28(1):39-46.

76. Dalgard O, Bjøro K, Hellum K, et al. Thyroid dysfunction during treatment of chronic hepatitis $\mathrm{C}$ with interferon alpha: no association with either interferon dosage or efficacy of therapy. J Intern Med. 2002;251(5):400-406.

77. Selmi C, Lleo A, Zuin M, Podda M, Rossaro L, Gershwin ME. Interferon alpha and its contribution to autoimmunity. Curr Opin Investig Drugs. 2006;7(5):451-456.

78. McHutchison JG, Dusheiko G, Shiffman ML, et al; TPL102357 Study Group. Eltrombopag for thrombocytopenia in patients with cirrhosis associated with hepatitis C. $N$ Engl J Med. 2007;357(22):2227-2236.

79. McHutchison JG, Ware JE Jr, Bayliss MS, et al; for Hepatitis Interventional Therapy Group. The effects of interferon alpha-2b in combination with ribavirin on health related quality of life and work productivity. J Hepatol. 2001;34(1):140-147.

80. Dalgard O, Egeland A, Skaug K, Vilimas K, Steen T. Health-related quality of life in active injecting drug users with and without chronic hepatitis C virus infection. Hepatology. 2004;39(1):74-80.

81. Muir AJ, Bornstein JD, Killenberg PG; Atlantic Coast Hepatitis Treatment Group. Peginterferon alfa-2b and ribavirin for the treatment of chronic hepatitis $\mathrm{C}$ in blacks and non-Hispanic whites. $N$ Engl J Med. 2004;350(22):2265-2271.

82. Rodriguez-Torres M, Jeffers LJ, Sheikh MY, et al; Latino Study Group. Peginterferon alfa-2a and ribavirin in Latino and non-Latino whites with hepatitis C. N Engl J Med. 2009;360(3):257-267.

83. Yan KK, Guirgis M, Dinh T, et al. Treatment responses in Asians and Caucasians with chronic hepatitis C infection. World J Gastroenterol. 2008;14(21):3416-3420.

84. Ge D, Fellay J, Thompson AJ, et al. Genetic variation in IL28B predicts hepatitis C treatment-induced viral clearance. Nature. 2009 Aug 16. [Epub ahead of print]. doi:10.1038/nature08309.

85. Yamashita T, Hashimoto $S$, Kaneko $S$, et al. Comprehensive gene expression profile of a normal human liver. Biochem Biophys Res Commun. 2000;269(1):110-116.
86. Yamashita T, Honda M, Takatori H, Nishino R, Hoshino N, Kaneko S. Genome-wide transcriptome mapping analysis identifies organ-specific gene expression patterns along human chromosomes. Genomics. 2004;84(5):867-875.

87. Bigger CB, Brasky KM, Lanford RE. DNA microarray analysis of chimpanzee liver during acute resolving hepatitis $\mathrm{C}$ virus infection. J Virol. 2001;75(15):7059-7066.

88. Su AI, Pezacki JP, Wodicka L, et al. Genomic analysis of the host response to hepatitis C virus infection. Proc Natl Acad Sci U S A. 2002;99(24):15669-15674.

89. Asselah T, Bièche I, Laurendeau I, et al. Liver gene expression signature of mild fibrosis in patients with chronic hepatitis C. Gastroenterology. 2005;129(6):2064-2075.

90. Bièche I, Asselah T, Laurendeau I, et al. Molecular profiling of early stage liver fibrosis in patients with chronic hepatitis $\mathrm{C}$ virus infection. Virology. 2005;332(1):130-144.

91. Lau DT, Luxon BA, Xiao SY, Beard MR, Lemon SM. Intrahepatic gene expression profiles and alpha-smooth muscle actin patterns in hepatitis C virus induced fibrosis. Hepatology. 2005;42(2): 273-281.

92. Smith MW, Walters KA, Korth MJ, et al. Gene expression patterns that correlate with hepatitis $\mathrm{C}$ and early progression to fibrosis in liver transplant recipients. Gastroenterology. 2006;130(1):179-187.

93. Ji X, Cheung R, Cooper S, Li Q, Greenberg HB, He XS. Interferon alfa regulated gene expression in patients initiating interferon treatment for chronic hepatitis C. Hepatology. 2003;37(3):610-621.

94. Chen L, Borozan I, Feld J, et al. Hepatic gene expression discriminates responders and nonresponders in treatment of chronic hepatitis $\mathrm{C}$ viral infection. Gastroenterology. 2005;128(5):1437-1444.

95. Hayashida K, Daiba A, Sakai A, et al. Pretreatment prediction of interferon-alfa efficacy in chronic hepatitis C patients. Clin Gastroenterol Hepatol. 2005;3(12):1253-1259.

96. Feld JJ, Nanda S, Huang Y, et al. Hepatic gene expression during treatment with peginterferon and ribavirin: Identifying molecular pathways for treatment response. Hepatology. 2007;46(5): 1548-1563.

97. Asselah T, Bieche I, Narguet S, et al. Liver gene expression signature to predict response to pegylated interferon plus ribavirin combination therapy in patients with chronic hepatitis C. Gut. 2008;57(4): 516-524.

98. Hwang Y, Chen EY, Gu ZJ, et al. Genetic predisposition of responsiveness to therapy for chronic hepatitis C. Pharmacogenomics. 2006;7(5):697-709.

99. Lin E, Hwang Y, Wang SC, Gu ZJ, Chen EY. An artificial neural network approach to the drug efficacy of interferon treatments. Pharmacogenomics. 2006;7(7):1017-1024.

100. Huang Y, Yang H, Borg BB, et al. A functional SNP of interferongamma gene is important for interferon-alpha-induced and spontaneous recovery from hepatitis C virus infection. Proc Natl Acad Sci USA. 2007;104(3):985-990.

101. Morgan TR, Lambrecht RW, Bonkovsky HL, et al; for HALT-C Trial Group. DNA polymorphisms and response to treatment in patients with chronic hepatitis C: results from the HALT-C trial. J Hepatol. 2008;49(4):548-556.

102. Persico M, Capasso M, Russo R, et al. Elevated expression and polymorphisms of SOCS3 influence patient response to antiviral therapy in chronic hepatitis C. Gut. 2008;57(4):507-515.

103. Welzel TM, Morgan TR, Bonkovsky HL, et al; for HALT-C Trial Group. Variants in interferon-alpha pathway genes and response to pegylated interferon-Alpha2a plus ribavirin for treatment of chronic hepatitis $\mathrm{C}$ virus infection in the hepatitis $\mathrm{C}$ antiviral long-term treatment against cirrhosis trial. Hepatology. 2009;49(6):1847-1858.

104. Asselah T, Bièche I, Sabbagh A, et al. Gene expression and hepatitis C virus infection. Gut. 2009;58(6):846-858.

105. Walters KA, Katze MG. Using high-throughput genomics to study hepatitis C: what determines the outcome of infection? Antiviral Res. 2009;81(3):198-208. 
106. McHutchison JG, Everson GT, Gordon SC, et al; PROVE1 Study Team. Telaprevir with peginterferon and ribavirin for chronic HCV genotype 1 infection. N Engl J Med. 2009;360(18):1827-1838.

107. Hézode C, Forestier N, Dusheiko G, et al; PROVE2 Study Team. Telaprevir and peginterferon with or without ribavirin for chronic HCV infection. N Engl J Med. 2009;360(18):1839-1850.
108. Kwo P, Lawitz E, McCone J, et al. HCV SPRINT-1 final results: SVR 24 from a phase 2 study of boceprevir plus PegIntron ${ }^{\mathrm{TM}}$ (Peginterferon alfa-2b)/ribavirin in treatment-naive subjects with genotype-1 chronic hepatitis C [abstract]. J Hepatol. 2009;50(1 Suppl):S4.

\section{Publish your work in this journal}

Pharmacogenomics and Personalized Medicine is an international, peer-reviewed, open access journal characterizing the influence of genotype on pharmacology leading to the development of personalized treatment programs and individualized drug selection for improved safety, efficacy and sustainability. This journal is indexed on the
American Chemical Society's Chemical Abstracts Service (CAS). The manuscript management system is completely online and includes a very quick and fair peer-review system, which is all easy to use. Visit http://www.dovepress.com/testimonials.php to read real quotes from published authors.

Submit your manuscript here: http://www.dovepress.com/pharmacogenomics-and-personalized-medicine-journal 